\title{
Anti diabetic potential of some selected traditionally used Medicinal Plants in Western Ghats of India w.s.r to Prameha
}

\author{
${ }^{1}$ Patekar Rashmi , ${ }^{2}$ Jais wal M.L., ${ }^{3}$ Neelam, ${ }^{4}$ Chaudhary Anubha , ${ }^{5}$ Hivale Ujwala \\ 1. Ph.D Scholar, P.G. Dept. of Dravyaguna Vigyan, National Institute of Ayurveda, Jaipur. \\ 2. Associate Prof., P.G. Department of Dravyaguna Vigyan, National Institute of Ayurveda, Jaipur, \\ ${ }^{3}$. Ph.D Scholar, P.G. Dept. of Dravyaguna Vigyan, National Institute of Ayurveda, Jaipur, \\ 4. M.D Scholar, P.G. Dept. of Dravyaguna Vigyan, National Institute of Ayurveda, Jaipur, \\ 5. Ph.D Scholar, P.G. Dept. of Panchakarma, National Institute of Ayurveda, Jaipur \\ Corresponding Author:

\section{Patekar Rashmi,}

P.G. Dept. of Dravyaguna Vigyan, National Institute of Ayurveda, Jaipur, Rajasthan, India.

\begin{abstract}
Traditional remedies are gaining worldwide acceptability. In the developing country like India safe, efficient and economic indigenous remedies are gaining popularity among the urban and rural areas. Diabetes is one of the major lifestyle disease which remains without a promising management solution in conventional medicine. In Ayurveda, this disease can be largely equated to a disease process called Prameha. The Western Ghats consists of unusual flora of Sahyadri hills representing dense and diversified vegetation. The people here are largely dependent on the available natural resources for food and medicine at primary level in treatment of diabetes. Not much work has been done so far for exploration of anti diabetic activity of these medicinal plants in correlation with its mode of action in perspective of Ayurveda texts and modern literature collectively. So the paper will highlight the anti diabetic potential of some selected medicinal plants used here for diabetic treatment through available Ayurveda literature and recent researches done so far.
\end{abstract}

Key Words: Traditional medicinal plants, Western Ghats (India), Anti diabetic potential, Prameha.

\section{Introduction}

Since time immemorial plants have been the basic source of therapeutic agents due to its easy availability, abundance and economic. World has gain success in inventing new modern interventions in the treatment of diseases but still a large number of population are utilizing the plant genetic resources as medicine occurring in their surrounding vegetation. About $80 \%$ of the people in the world rely on traditional medicine including ethno medicine for primary health care (WHO). Traditional medicines give a clue to further drug development from available natural resources. As per Ayurveda literature, not a single plant available in nature is devoid of medicinal properties ${ }^{1}$ and so if used rationally can proved of paramount importance in treatment of complex disorders. Some plants acts through their rasa (taste), some through their virya (active principle), some through their vipaka (end metabolism) and some through their prabhava (specific action) ${ }^{2}$. Biological actions of plants used as an alternative medicine to treat disease are related to their chemical composition.

Diabetes is a serious, chronic disease that occurs either when the pancreas does not produce enough insulin (a hormone that regulates blood glucose), or when the body cannot effectively use the insulin it produces ${ }^{3}$. It 
has been the major problem rising more rapidly in middle and low income countries. WHO projects that diabetes will be the $7^{\text {th }}$ leading cause of death in 2030. According to latest data the International Diabetes Federation estimated that 194 million people live with diabetes worldwide and this number will rise to 333 million in $2025^{4}$. It is a complex metabolic disorder, as such difficult to cure completely using single health care system. So there is need to search for easily available natural plant resources to mitigate this problem entirely. In Ayurveda, this disease can be largely equated to a disease process called Prameha. The cardinal feature of Prameha is 'Prabhutavila Mutrata' which means frequent and copious urine with turbidity (Vagbhata).

The Western Ghats, one of the hottest biodiversity hotspots characterized with high degree of biodiversity in floristic composition, second only to the great Himalayan Mountain ranges in India. It extend from the Satpura Range in the north, stretching from Gujarat to Tamil Nadu crossing the states of Maharashtra, Goa, Karnataka, and Kerala. The region receives heavy rainfall annually and it therefore abounds in a variety of fairly unusual flora. Due to dense and diversified vegetations local healers are largely dependent on their traditional healing system for the primary healthcare. Several medicinal plants used traditionally have been described in the scientific and popular literature as having anti diabetic activity. The paper will discuss the anti diabetic potential of some selected medicinal plants used here for diabetic treatment through the basic pharmacological principles (Rasapanchaka) of plants and naturally occurring bio active constituents.

\section{Enumeration of anti diabetic activity of some traditionally used medicinal plants.}

\section{Amalaki [Phyllanthus emblica L.]}

Amalaki, one of the most commonly used important herbs in Ayurveda system of medicine. The fruit has five rasa (tastes), with Amla (sour) and Kashaya (astringent) being the most dominant, including madhura (sweet), tikta (bitter) and katu (pungent). Virya is sheeta (cold potency), vipaka madhura (Sweet) and guna (qualities) laghu (easy to digest), ruksha (that which causes dryness in the tissues). It pacifies all three dosha - vata, pitta and kapha. Fruit is edible and taken in the form of food or medicine in diabetes ${ }^{5}$. It is a rich source of Vit $\mathrm{C}$ content, which is effective in controlling diabetes. It stimulates the pancreas and enables it to secrete insulin, thus reducing the blood sugar in diabetes ${ }^{6}$. Tannins, alkaloids and phenolic compounds are constituents of amla. Tannoids of Phyllanthus emblica $L$ inhibits osmotic stress and prevents hyperglycemia-induced oxidative stress due to the inhibition of the polyol pathway possibly ${ }^{7}$. Polyphenols is abundant in fruit juice (541.3 mg gallic acid equivalent/1 g extract) which might be accountable for glucose and lipid lowering effects, also might be responsible for cardioprotective effects ${ }^{8}$.

\section{Beejaka [Pterocarpus marsupium Roxburgh]}

Beejaka, an 'Indian Kino tree' is considered as one of the potent anti diabetic drugs of herbal origin. Bark has been used in treatment of diabetes in folklore ${ }^{5,9}$. Beejaka is kashaya, tikta in rasa, having ushna virya (hot potency), katu (bitter) vipaka (end metabolism) and laghu, ruksha properties. It pacifies kapha and pitta dosha. Bark extract was found to induce insulin release from pancreatic cells ${ }^{10}$. Phenolic-C-glycosides present in the heart wood are the active constituents responsible for the antihyperglycemic activity ${ }^{11}$. Marsupsin and pterostilbene, phenolic constituent, present in heartwood were found to reduce blood glucose level ${ }^{12}$.

\section{Guduchi [Tinospora cordifolia (Willd.)]}

Guduchi is one of the non controversial and extensively used herbs in Ayurveda medicine. A large climber with succulent corky and grooved stems distributed almost throughout India. Stem and leaf has been use in diabetes in ethno medical practice ${ }^{13}$. It is tikta (bitter), kashaya (astringent) in rasa, having ushna virya, katu vipaka and guru (heavy to digest), snigdha (unctuousness) properties. It pacifies all three dosha-vata, pitta and kapha. Recent researches proved that isoquinoline alkaloid rich fraction and three alkaloids viz., palmatine, jatrorrhizine and magnoflorine derived from stem showed insulin-mimicking and insulinreleasing effect ${ }^{14}$. Stem extract induced regeneration of the pancreatic islets cells ${ }^{15}$ and increased glycogen 
storage in the liver ${ }^{16}$. Ethanolic extract of leaf showed anti diabetic action through some peripheral mechanisms, either by increasing the glycogen storage in the liver or by decreasing the glucose release from the liver $^{17}$.

\section{Haridra [Curcuma longa L.]}

Haridra, popularly known as 'Turmeric' is extensively used as a spice. In the Ayurveda literature it is most commonly used herb both internally and externally in the treatment of various ailments. Rhizome has been used for diabetes treatment in folk lore ${ }^{18}$. It is tikta, katu in rasa, having ushna virya, katu vipaka and laghu, ruksha properties. It is tridosha shamaka (pacifies all three dosha - vata, pitta and kapha). Curcumin, an active constituent present in rhizome was found to protect the islets $\beta$-cell, decreases the insulin resistance and the oxidative stress ${ }^{19}$. Curcumin, demethoxycurcumin, bisdemethoxycurcumin, and ar-turmerone, the main constituents of rhizome suppressed the increase blood glucose level and contributed to the effect via peroxisome proliferator-activated receptor (PPAR)-gamma activation ${ }^{20}$.

Jambu [Syzigium cumini (L.) Skeels.]

$J a m b u$, a well known drug used in alternative health care system. Fruits are edible and its seeds and bark has been used commonly in the treatment of diabetes in folklore ${ }^{13}$. It is kashaya, madhura in rasa, having sheeta virya, katu vipaka and laghu, ruksha properties. It pacifies kapha and pitta dosha. The ethyl acetate and methanol extracts of seed showed anti diabetic activity. The isolated compound, mycaminose from seed was responsible to decrease in blood sugar level. The possible action may be by potentiation of the insulin effect of plasma by increasing either the pancreatic secretion of insulin from beta-cells of the islets of Langerhans or its release from the bound form ${ }^{21}$. Bark showed the presence of flavonoids or polyphenolics compounds such as quercetin, isoquercetin, myricetin, anthocynin etc. Flavonoids or polyphenols present are reported for their anti diabetic activity ${ }^{22}$. Anthocyanins, the natural colorants have also been shown to stimulate insulin secretion from pancreatic beta-cells in vitro ${ }^{23}$. Myricetin, a naturally occurring flavonoid, lowered blood glucose through improved glucose utilization ${ }^{24}$.

Kaidarya [Murraya koenijii (L.) Spreng.]

Kaidarya, also known as curry tree is commonly used in Indian food receipe. Leaf has been used by tribals in diabetes ${ }^{18}$. It is tikta, kashaya in rasa having sheeta virya, katu vipaka and laghu, ruksha properties. It pacifies kapha and pitta dosha. Recent researches proved that leaf extract - increases insulin secretion and enhances the glycogenesis process ${ }^{25}$. Mahanimbine, carbazole alkaloid from Murraya koenigii leaves has alpha amylase inhibitory and alpha glucosidase inhibitory effect useful in management of postprandial hyperglycemia. Mahanimbine increases the pancreatic secretion of insulin from beta cells of islets of langerhans and the peripheral glucose uptake ${ }^{26}$.

\section{Kaalmegh [Andrographis paniculata Nees.]}

Kaalmegh, 'The King of Bitters' frequently used in traditional medicines and Ayurveda health care system to treat array of diseases. Due to its strong bitter taste, folk lore believed to utilize this plant in the treatment of diabete ${ }^{27}$. It is tikta in rasa, having sheeta virya, katu vipaka and laghu, ruksha properties. It pacifies kapha and pitta dosha. The ethanolic extract of leaf is known to possess anti diabetic activity. Andrographolide, an active principle in the leaves increases glucose utilization to lower plasma glucose in diabetic rats lacking insulin ${ }^{28}$ Ethanol extract of leaf was found to be non toxic as seen by the normal creatinine and urea levels in the extract fed normal rats. There was an increase in the activity of liver antioxidant enzymes. Histopathological study of pancreas revealed the islet cell restoring and regenerative ability of $A$. paniculata extract ${ }^{29}$.

Saptachakra [Salacia sp.] 
Several species have been reported as Saptachakra on the basis of its root characteristics (seven circles on cross section). Salacia chinensis L., Salacia macrosperma Wight and Casearia esculanta Roxb. are some of the important ones used traditionally in the treatment of diabetes ${ }^{5}$. The root decoction of these plants has been found to be effective. Saptachakra is kashaya (astringent), tikta (bitter) in rasa, having ushna virya (hot potency), katu vipaka (pungent product after end metabolism) and laghu (easy to digest), ruksha (that which causes dryness in the tissues), tikshna (fast acting or that which is stimulatory in action) properties. It pacifies kapha and pitta dosha. Recent researches showed that salacinol, katnanol, mangiferin, the active principles present in root of Salacia sp inhibited $\alpha$-glucosidase enzyme and slowed down the absorption of glucose in intestine ${ }^{30}$. Mangiferin isolated from Salacia chinensis regulated the kidney carbohydrate metabolism in diabetic rats ${ }^{31}$ and effectively regenerated insulin secreting islet cells ${ }^{32}$. Ethanolic extract of root of Casearia esculenta stimulated insulin secretion from the remanent $\beta$ cells or/and from regenerated $\beta$ cells $^{33}$. Its root extract was found to be effective in oxidative stress induced diabetes.

Kutaja [Holarrhena antidysenterica (Linn.)Wall.]

Kutaja, a small deciduous tree commonly found in tropical parts of India. Charaka quoted Kutaja tvak (bark) as the best Sangrahaka (Anti diarrheal) dravya. Kutaja is tikta, kashaya in rasa, having sheeta virya (cold potency), katu vipaka and laghu, ruksha properties. It pacifies kapha and pitta dosha. Traditionally bark has been used in the treatment of diabetes ${ }^{5}$. Presence of flavonoides, phenolic compounds present in bark were found to be responsible for antioxidant and antidiabetic activity ${ }^{34}$. Bark extract showed improvement in liver glycogen and glucose uptake ${ }^{35}$.

Meshashringi [Gymnema sylvestris R.Br]

Meshashringi, popularly called as Gudmar (destroyer of sweet taste) in Hindi as chewing the leaves cause loss of sweet taste. Leaves are extensively used in the diabetes management both by folk and traditional vaidya $^{27}$. It is tikta, kashaya in rasa, having ushna virya, katu vipaka and laghu, ruksha properties. It pacifies kapha and vata dosha. Recent researches proved that, the gymnemic acid (glycoside), a bitter principle found in leaf extracts significantly increased the regeneration of $\beta$-cells in Type 2 diabetic. This may be due to regeneration of beta cells ${ }^{36,37}$.

Manjistha [Rubia cordifolia Linn.]

Manjistha, commonly known as Indian madder is famous as Rakta shodhaka (blood purifier) in the traditional medicine, also used for treatment of various ailments like diabetes ${ }^{18}$, cancer etc.. It is tikta, kashaya, madhura in rasa, having ushna virya, katu vipaka and guru, ruksha properties. It pacifies kapha and pitta dosha. Root was found to show the presence of phenols and flavonoids ${ }^{38}$, which are reported to possess anti diabetic activity.

Nimba [Azadirachta indica A. Juss.]

Nimba most commonly used plant in the indigenous system of medicine in the treatment of skin diseases. It is tikta, kashaya in rasa, having sheeta virya, katu vipaka and laghu, ruksha properties. It pacifies kapha and pitta dosha. The anti diabetic activity of the leaf used ethno medicinally ${ }^{13}$ can be attributed to its action to stimulate sufficient production of insulin by the pancreas and regenerate the $\beta$-cells to carry out its functions ${ }^{39}$. Few researches carried out reported that quercetin, rutin, and nimbidin the active components present in leaf extract were responsible for anti diabetic activity. Rutin and quercetin (flavonoids) both possessed high antioxidant activity ${ }^{40}$. Rutin had the ability to scavenge free radicals, inhibit lipid proxidation and protect the $\beta$ cells of the pancreas ${ }^{41}$ whereas quercetin found to preserve pancreatic $\beta$ cell integrity ${ }^{42}$.

\section{Sadampushpa [Catharanthus roseus Linn.]}

Sadampushpa commonly known as the Madagascar periwinkle or Vinca rosea is well known in modern medicine for its anti cancer effect. The flower and leaf has been used by local healers to treat diabetes ${ }^{5,13}$. It is tikta (bitter), kashaya (astringent) in rasa, having ushna virya (hot potency), katu vipaka and laghu, 
ruksha properties. It pacifies vata and kapha dosha. Antihyperglycemic activity reported which found to increase plasma insulin concentration ${ }^{43}$ and insulin sensitivity. Alkaloids- vindoline I, vindolidine II, vindolicine III and vindolinine IV present in leaf extract were attributed to anti diabetic activity through high glucose uptake in pancreatic beta cells ${ }^{44}$.

\section{Saptaparna [Alstonia scholaris R.Br.]}

Saptaparna popularly known as Devil's tree is a well known remedy known for the treatment of diabetes in the folk ${ }^{5}$ and various other disorders in Ayurveda system of Indian medicine. It is tikta, kashaya in rasa, having ushna virya, katu vipaka and laghu, snigdha properties. It pacifies kapha and pitta dosha. The antidiabetic effect of the bark extract found was possibly due to increased utilization of glucose by peripheral tissues, improved sensitivity of target tissues for insulin or it may be due to improved metabolic regulation of glucose $e^{45}$.

\section{Sariva [Hemidesmus indicus $\mathrm{R} . \mathrm{Br}$.]}

Sariva, commonly known as Indian Sarsaparilla is generally used in the Ayurveda System of Medicine for treatment of skin diseases but root also has been used in diabetes in folklore ${ }^{18}$. It is madhura (sweet), tikta (bitter) in rasa, having sheeta virya, madhura vipaka and guru, snigdha properties. It pacifies all the three dosha - vata, pitta and kapha. The root extract showed stimulatory effect on the regenerating beta-cells and also on the surviving beta-cells ${ }^{46}$. Root had Isovanillic acid 3-Hydroxy-4-methoxy-benzoic acid present in it which lowered the blood sugar level.

\section{Discussion}

The plants mentioned above are predominantly with tikta (bitter) rasa, followed by katu (bitter), kashaya (Astringent), madhura (sweet) and amla (sour) anurasa (sub-taste) having either ushna or sheeta virya (hot or cold potency). All plants have katu vipaka and are laghu (easy to digest), ruksha (Dryness or nonunctuousness) in guna (quality) except amalaki with madhura vipaka, guduchi with madhura vipaka and guru, snighdha guna (quality), manjistha-guru, ruksha in guna and sariva with guru, snigdha guna. Usually the bitter taste plants are found to be traditionally used in diabetes management. It may be due to a strong belief that plants having tikta (bitter) rasa (taste) alleviates symtoms of Diabetes and intake of madhura (sweet) rasa dravya (diet or drug) worsen the condition of diabetic patients. Diabetes is a metabolic disorder which can be correlated with Prameha mentioned in Ayurveda classics. Charaka quoted the general causative factor responsible for Prameha as especially intake of kapha prakopaka (that which vitiates kapha dosha) ahara (food) and vihara (Exercise) ${ }^{47}$. Kapha causative factors either cause kapha dosha vitiation directly or in association with pitta dosha may cause obstruction in the channels thus responsible for vata dosha vitiation. Thus we can say in Prameha all the three dosha are vitiated which according to their dominance manifests their symptoms accordingly. Vitiated dosha affects meda dhatu (fat tissue), mamsa dhatu (muscle tissue) kleda (liquid element), etc. of body and draws the tissue elements into the urinary tract, which eventually causes the disease Prameha ${ }^{48}$. Tikta, and kashaya rasa due to ushna and tikshna guna are kaphashamaka (alleviates vitiated kapha), absorbs meda dhatu and also shareeraja kleda, the important factor involved in Prameha which may indirectly maintain the expulsion of excessive urine 49,50,51,52. Tikta and katu rasa also by its deepana (digestive stimulant) and pachana (digestant) action improves the impaired digestion involve in the pathogenesis of Prameha. Tikta ${ }^{51}$ and kashaya rasa ${ }^{52}$ has lekhana (scrapping) action whereas Charaka quoted action of katu rasa as 'Margaana Vivrunoti' (i.e clears the obstructed channels) ${ }^{49}$. Thus, tikta, katu rasa, katu vipaka, ushna virya and ruksha guna facilitate to take out the excess meda deposition in the body, thereby ultimately contributing to break down the pathogenesis taking place in obstructed channels. Some plants found to possess madhura-tikta rasa where madhura rasa in association with tikta rasa can provide strengthening to the organs of urinary system thereby reducing the further complications of diabetes. Ushna virya of plants due to their deepana and pachana action also improves digestion in association with tikta, katu rasa. Considering the guna (quality) of plants, even laghu, ruksha and tikshna guna may also contribute in reducing vitiated kapha and involved 
kleda and medodhatu. Immunomodulatory drugs like amalaki, guduchi, haridra, sariva due to their specific bhoutika configuration (vichitra pratyayarabdhatwa - exhibit pharmacological activity not according to its structural constituents) or rasayana (rejuvenating) prabhava (special action) maintains the dhatu kshaya (tissue emaciation) taking place in diabetes, regulates the disturbed metabolism thus reducing the symptoms of diabetes and the complications involved.

The above data revealed that the presence of naturally present various flavonoids, polyphenolic compounds or alkaloids in the plant are responsible for anti diabetic activity. They act either by promoting regeneration of is let cells, increasing insulin secretion or increasing sensitivity of tissues to insulin or reducing absorption of glucose from gastrointestinal tract or by lowering blood glucose level through improved peripheral utilization of glucose. Flavonoids also act as good anti oxidant ${ }^{53}$. Anti oxidant property of plants pacifies oxidative stress induce diabetes either by inhibition of superoxide radicals or hydroxyl radical scavenging activity or inhibition of lipid peroxidation or by converting ROS (reactive oxygen species) to non reactive products.

\section{Conclusion}

This review presented a comprehensive detail of the factors attributed to the anti diabetic activity of plants. Usually naturally available plant based medicines used by people from every culture and various indigenous medicines are gradually being introduced into modern therapeutics. The above documented plants showed anti diabetic activity either through the presence of basic pharmacological principles (Rasapanchaka) of plants or through naturally occurring bio active constituents responsible for regeneration ability of beta cells of pancreas. So the people in the earliest stages of the disease could be treated to delay or prevent full-blow clinical diabetes. Thus the knowledge of traditional medicine and medicinal plants and their study of scientific chemical principles can prove beneficial in the discovery of newer and cheaper drugs.

\section{References}

1. Agnivesha: Charaka Samhita, Ayurveda Dipika Commentary by Chakrapani, Ed. Pt. Y T Acharya: New Delhi, Rastriya Sanskrit Samsasthan; Reprint 2011, verse no Charaka Sutrasthana 26/12.

2. Agnivesha: Charaka Samhita, Ayurveda Dipika Commentary by Chakrapani, Ed. Pt. Y T Acharya: New Delhi, Rastriya Sanskrit Samsasthan; Reprint 2011, verse no Charaka Sutrasthana 26/71.

3. Definition, Diagnosis and Classification of Diabetes Mellitus and its Complications. Part 1: Diagnosis and Classification of Diabetes Mellitus (WHO/NCD/NCS/99.2). Geneva: World Health Organization; 1999.

4. Din N, Dibong SD, Mopondo Mopondo E, Priso RJ, Kwin NF et al. Inventory and Identification of plants Used in the Treatment of Diabetes in Doula Town (Cameroon), 2011; 1(3):60-73.

5. Patekar Rashmi, Jaiswal M.L., Survey of some traditionally used Anti diabetic Plants in Amboli region of Maharashtra, India in perspective of Ayurveda. Journal of Medicinal Plant Studies, 2017; 5(2): 343-347.

6. Patel S.S and Goyal R.K., Prevention of diabetes-induced myocardial dysfunction in rats using the juice of the Emblica officinalis fruit. Exp Clin Cardiol., 2011; 16(3):87-91.

7. Kimura K., Role of essential trace elements in the disturbance of carbohydrate metabolism, Nippon Rinsho, 1996; 54: 79-84.

8. Subramanian V., Butler L.G., Jambunathan R. and Prasada Rao K.E., Some agronomic and biochemical characters of brown sorghums and their possible role in bird resistance. J. Agric. Food Chem., 1983; 31:1303-1307.

9. 9]Rekha R. Deokar, Shubhangi R. Kamble, Satish R. Mane and Sarjerao R. Patil, Survey of Ethno medicinal Plants with Antidiabetic Potential from Chandoli, Dist. Sangli, (M.S.) India. Journal of Pharmacy Research, 2012; 5(2):1001-1003.

10. A.Maruthupandian and V.R. Mohan. Antidiabetic, Antihyperlipidaemic and Antioxidant activity of Pterocarpus marsupium Roxb. in alloxan induced diabetic rats. International Journal of PharmTech Research, 2011;3(3):1681-1687. 
11. Mishra A, Srivastava R, Srivastava SP, Gautam S, Tamrakar AK, Maurya R, Srivastava AK. Antidiabetic activity of heart wood of Pterocarpus marsupium Roxb. and analysis of phytoconstituents. Indian J Exp Biol. 2013; 51(5):363-74.

12. Manickam M, Ramanathan M, Farboodniay Jahromi MA, Chansouria JPN, Ray AB Antihyperglycemic activity of phenolics from Pterocarpus marsupium. J Nat Prod, 1997; 60:609610.

13. Vidyasagar GM, Siddalinga Murthy S M, Medicinal Plants used in the treatment of Diabetes mellitus in Bellary district, Karnataka. Indian Journal of Traditional Knowledge, 2013; 12(4):747-751.

14. Mayurkumar Patel, Shrihari H Mishra, Hypoglycemic activity of alkaloidal fraction of Tinospora cordifolia, Phytomedicine: international journal of phytotherapy and phytopharmacology, 2011; 18(12):1045-52 .

15. Kinkar Shobha B., Patil Kishor Gopal. Anti diabetic Activity of Tinospora cordifolia (Fam. Menispermaceae) in Alloxan \Treated Albino Rats. Applied Research Journal, 2015; 1(5): 316-319.

16. Nagaraja Puranik, Kararashah Fakruddin Kammar, Sheela Devi; Anti-diabetic activity of Tinospora cordifolia (Willd.) in streptozotocin diabetic rats; does it act like sulfonylureas?; Turk J Med Sci, 2010; 40 (2): 265-270.

17. Chandra Shekhar Singh, Amit Kumar Singh, Sonam Khandelwal, Ratanlal Vishwkarma. AntiDiabetic Activity of Ethanolic Extract of Tinospora Cordifolia Leaves. Int. J. of Drug Discovery \& Herbal Research, 2013; 3(1): 601-604.

18. K Aadhan and SP Anand, Survey of medicinal plants used for the treatment of diabetes by the Paliyar's Tribe in Sadhuragiri hills, Tamil Nadu, India. International Journal of Herbal Medicine, 2017; 5(3):17-25.

19. Roman Adhikari, Jyoti Y, Deepika Bora, Vamsee Veena A, Combined Effect of Aqueous Extract of Curcuma longa Linn. with Metformin in Diabetes Induced Neuropathic Pain in Rats. Asian Journal of Pharmaceutical and Clinical Research, 2015; 8(5).

20. Kuroda M, Mimaki Y, Nishiyam T, Mae T, Kishida H, Tsukagawa M, Takahashi K, Kawade T, Nakagawa K, Kitahara M. Hypoglycemic effects of turmeric (Curcuma longa L. rhizomes) on genetically diabetic KK-Ay mice. Biol Pharm Bull., 2005; 28(5): 937-9.

21. A. Kumar, R. Ilavarasan, T. Jayachandran, M. Deecaraman, P. Aravindan, N. Padmanabhan and M. R. V.Krishan. Anti-diabetic activity of Syzygium cumini and its isolated compound against streptozotocin-induced diabetic rats. Journal of Medicinal Plants Research, 2008; 2(9): 246-249.

22. 22]Saravanan G, Leelavinothan P. Effects of Syzygium Cumini Bark on Blood Glucose, Plasma Insulin and C-peptide in Streptozotocininduced Diabetic rats. Int J Endocrinol Metab., 2006; 4: 96105.

23. Jayaprakasam B, Vareed SK, Olson LK, Nair MG. Insulin secretion by bioactive anthocyanins and anthocyanidins present in fruits. J Agric Food Chem, 2005; 53: 28-31.

24. Ong KC, Khoo HE. Effects of myricetin on glycemia and glycogen metabolism in diabetic rats. Life Sci., 2000; 67: 1695-705.

25. Dr.S.Vijayanand. Evaluation of Antidiabetic activity of Murraya koenigii on Alloxan Induced Diabetic rats. International Journal of Pharma Sciences and Research, 2015; 6 (12).

26. B. Dineshkumar, Analava Mitra, Manjunatha Mahadevappa. Antidiabetic and hypolipidemic effects of mahanimbine (carbazole alkaloid) from murraya koenigii (rutaceae) leaves. International Journal of Phytomedicine, 2010; 2: 22-30.

27. P.Durairaj \& M.Kamaraj, Traditional Medicinal Plants Resources of Southern Panchchamalais in Trichirapalli DT Tamilnadu, India: Implication of Traditional Knowledge in Health Care System. IMPACT: International Journal of Research in Humanities, Arts and Literature, 2013; 1(6):39-46.

28. Nalamolu Koteshwar Rao. Anti-Hyperglycemic and Renal Protective Activities of Andrographis paniculata Roots Chloroform Extract. Iranian Journal of Pharmacolgy \& Therapeutics, 2006; 5(1):47-50.

29. Ramya Premanath, Lakshmidevi Nanjaiah. Antidiabetic and Antioxidant potential of Andrographis paniculata Nees. leaf ethanol extract in streptozotocin induced diabetic rats. Journal of Applied Pharmaceutical Science, 2015; 5(1): 069-076. 
30. Ramakrishna D, Shashank .A.T., Shinomol George. K., Kiran.S, and Ravishankar. G.A' 'Salacia Sps - A Potent Source of Herbal Drug for Antidiabetic and Antiobesity Ailments : A Detailed Treatise. International Journal of Pharmacolognosy and Phytochemical Research, 2015; 7(2).

31. Periyar Selvam Sellamuthu, Palanisamy Arulselvan, Balu Periamallipatti Muniappan. Effect of mangiferin isolated from Salacia chinensis regulates the kidney carbohydrate metabolism in streptozotocin-induced diabetic rats. Asian Pacific Journal of Tropical Biomedicine; 2012, 2(3):1583-1587.

32. Periyar Selvam Sellamuthu, Palanisamy Arulselvan, Balu Periamallipatti Muniappan, Sharida Fakurazi, and Murugesan Kandasamy. Mangiferin from Salacia chinensis Prevents Oxidative Stress and Protects Pancreatic $\beta$-Cells in Streptozotocin-Induced Diabetic Rats. Journal of Medicinal Food, 2013; 16(8): 719-727.

33. Balasubramanian Arul, Ramalingam Kothai a, Arokiasamy Josephine Maria Christina. Hypoglycemic Activity of Casearia esculenta Roxb. in Normal and Diabetic Albino Rats. Iranian Journal of Pharmaceutical Research, 2006; 5(1): 47-51.

34. Bhusal A, Jamarkattel N, Shrestha A, Lamsal NK, Shakya S, Rajbhandari S. Evaluation of antioxidative and antidiabetic activity of bark of holarrhena pubescens wall, 2014; 8(9).

35. D.D. Bandawane, K.H. Bibave, A.V. Jaydeokar, U.S. Patil and M.G. Hivrale. Antihyperglycemic and Antihyperlipidemic Effects of Methanolic Extract of Holarrhena antidysenterica Bark in Alloxan Induced Diabetes Mellitus in Rats. Pharmacologia, 2013; 4(2).

36. 36]A Bakrudin Ali Ahmed, A.S Rao, M.V Rao. In vitro callus and in vivo leaf extract of Gymnema sylvestre stimulate $\beta$-cells regeneration and anti-diabetic activity in Wistar rats. Phytomedicine, 2010; 17(13):1033-1039

37. Nimisha Verma, V.K. Shakya and R.C. Saxena. Antidiabetic Activity of Glycoside Isolated from Gymnema sylvestre in Streptozotocin Induced Diabetic Rats. Asian Journal of Chemistry, 2008; 20(7): 5033-5036.

38. Sandhya Rani, Pallavi Mandave, Suresh Khadke, Suresh Jagtap, Shankar Patill and Aniket Kuvalekar. Antiglycation, Antioxidant and Antidiabetic activity of Traditional Medicinal Plant: Rubia cordifolia Linn. for management of Hyperglycemia. International Journal of Plant, Animal and Environmental Sciences, 2013; 3(3).

39. Henry D. Akpan, Itemobong S. Ekaidem, Itoro F. Usoh, Patrick E. Ebong and N.B. Isong. Effect of Aqueous Extract of Azadirachta indica (Neem) Leaves on Some Indices of Pancreatic Function in Alloxan-induced Diabetic Wistar Rats. Pharmacologia, 2012; 3(9).

40. Chattopadhyay RR. Possible mechanism of antihyperglycemic effect of Azadirachta indica leaf extract: part V. J Ethnopharmacol, 1999; 67(3):373-6.

41. Alsaif MA. Beneficial Effects of Rutin and Vitamin C Coadministration in a Streptozotocin-Induced Diabetes Rat Model of Kidney Nephrotoxicity. Pak J Nutr, 2009; 8(6):745-54.

42. Coskun O, Kanter M, Korkmaz A, Oter S. Quercetin, a flavonoid antioxidant, prevents and protects streptozotocin-induced oxidative stress and beta-cell damage in rat pancreas. Pharmacol Res., 2005; 51(2):117-23.

43. Karuna Rasineni, Ramesh Bellamkonda, Sreenivasa Reddy Singareddy and Saralakumari Desireddy. Antihyperglycemic activity of Catharanthus roseus leaf powder in streptozotocin-induced diabetic rats. Pharmacognosy Research, 2010; 2(3): 195-201.

44. Tiong SH, Looi CY, Hazni H, Arya A, Paydar M, Wong WF, Cheah SC, Mustafa MR, Awang K. Antidiabetic and antioxidant properties of alkaloids from Catharanthus roseus (L.) G. Don. Molecules, 2013; 18(8).

45. Bandawane D, Juvekar A, Juvekar M. Antidiabetic and Antihyperlipidemic Effect of Alstonia scholaris Linn. Bark in Streptozotocin Induced Diabetic Rats. Indian Journal of Pharmaceutical Education and Research, 2011; 45(2).

46. Gayathri Mahalingam, Krishnan Kannabiran. Hemidesmus indicus root extract ameliorates diabetesmediated metabolic changes in rats. International Journal of Green Pharmacy, 2009. 
${ }^{1}$ Patekar Rashmi , International Journal of Ayurvedic \& Herbal Medicine 7(4) July.-Aug.2017 (2663-2671)

47. Agnivesha: Charaka Samhita, Ayurveda Dipika Commentary by Chakrapani, Ed. Pt. Y T Acharya: New Delhi, Rastriya Sanskrit Samsasthan; Reprint 2011, verse no Charaka Chikitsasthana 6/4.

48. Agnivesha: Charaka Samhita, Ayurveda Dipika Commentary by Chakrapani, Ed. Pt. Y T Acharya: New Delhi, Rastriya Sanskrit Samsasthan; Reprint 2011, verse no Charaka Chikitsasthana 6/5-6.

49. Agnivesha: Charaka Samhita, Ayurveda Dipika Commentary by Chakrapani, Ed. Pt. Y T Acharya: New Delhi, Rastriya Sanskrit Samsasthan; Reprint 2011, verse no Charaka Sutrasthana 26/43-4.

50. Sushruta, Sushrutasamhita, with Nibandhasangraha Commentary Of Sri Dalhanacarya Ed. Vd. Yadavaji Trikamji Acharya \& Narayana ram Acharya "Kavyatirtha", Chaukhamba Orientalia, Varanasi; Reprint 2013, verse no Sushrut Sutrasthana 42/10-4.

51. Agnivesha: Charaka Samhita, Ayurveda Dipika Commentary by Chakrapani, Ed. Pt. Y T Acharya: New Delhi, Rastriya Sanskrit Samsasthan; Reprint 2011, verse no Charaka Sutrasthana 26/43-5.

52. Sushruta, Sushrutasamhita, with Nibandhasangraha Commentary Of Sri Dalhanacarya Ed. Vd. Yadavaji Trikamji Acharya \& Narayana ram Acharya "Kavyatirtha", Chaukhamba Orientalia, Varanasi; Reprint 2013, verse no Sushrut Sutrasthana 42/10-6.

53. Slobodan V., Jovanovic, Steen Steenken, Mihajlo Tosic, Budimir Marjanovic, Michael G. Simic. Flavonoids as Antioxidants. J.A.Chem.Soc., 1994; 116(11): 4846-4851. 